\title{
The Effect of Irrigation Scheduling and Mucuna Pod Granule on Yield of Orange Fleshed Sweet Potato (Ipomoea Batata)
}

\author{
Tolubanwo, S.E. ${ }^{1}$; Okereke, N.A.A ${ }^{2}$; Oti, N.N ${ }^{3}$; Nwandikom, G.I ${ }^{4}$, and Madubuike, C.N ${ }^{5}$ \\ ${ }^{I}$ National Root Crops Research, Institute Umudike (NRCRI) \\ ${ }^{2,3,4,5}$ Federal University of Technology Owerri (FUTO) \\ DOI: https://dx.doi.org/10.51244/IJRSI.2021.8313
}

\begin{abstract}
The experiment was carried out during the 2017 and 2018 dry season to evaluate irrigation scheduling and mucuna pod granule fertilizer on the yield of orange-fleshed sweet potato (OFSP). The treatments are made up of four fertilizer rates $(0$, 200,400 and $600 \mathrm{~kg} / \mathrm{ha}$ ), one irrigation method (Furrow), three irrigation scheduling (once every two days (E2D), once every three days (E3D) and once every four days (E4D) and one OFSP variety (mother delight). The experiment's design was arranged in a Randomized Complete Block Design (RCBD) replicated three times. The size of the plot was $4 \mathrm{~m} \times 5.1 \mathrm{~m}$, and there are 36 plots with a one-meter alley within plots and two meters between reps. The average irrigation duration per plot was nine minutes. The mucuna pod was harvested, dried, ground and its chemical composition was determined. The actual volume of the mucuna pod required for the experiment was calculated, and the same applied to the plots. After harvest, the treatments of $600 \mathrm{~kg} / \mathrm{ha}$ rate $(600 \mathrm{M})$ and E3D for 2017 gave the highest average weight of Vine (12.46t ha-1 and 11.16t ha-1), total weight of roots (9.11t ha1 and 9.44t ha-1) and marketable roots (8.89t ha-1 and 7.22t h-1). While in 2018 , the treatments of $600 \mathrm{~kg} / \mathrm{ha}$ rate $(600 \mathrm{M})$ and E3D for 2018 gave the highest average weight of Vine (31.77t ha-1 and 27.03t ha-1), total weight of roots (20.78t ha-1 and 16.28t ha-1) and marketable roots $(19.47 \mathrm{t}$ ha-1 and $15.23 \mathrm{t}$ ha-1). The $600 \mathrm{M} / \mathrm{E3D}$ also gave the highest weight of Vine + leave, weight of root, root girth and root length per stand. The profits of the produce sold for both years from NPK and Mucuna wereN $238,139.5$ and $N$ 426,078.4 respectively. We can conclude from this study, that $600 \mathrm{M} / \mathrm{E} 3 \mathrm{D}$ gave the highest yield when compared to other treatments in the tables and should be recommended.
\end{abstract}

Keywords: Irrigation scheduling, Fertilizer rate, mucuna pod fertilizer, orange-fleshed sweet potato, yield components.

\section{INTRODUCTION}

Neet potato [Ipomoea batatas (L.) Lam] is one of the most important crop found in sub-Saharan African (S.S.A.). This crop belongs to the Convolvulaceae family, as stated in Sheth et al. 2017 report. OFSP contains Carotenoid, which is a source of vitamin A used by most developing Countries to control vitamin A deficiency globally (Harvest Plus, 2009). It is grown for its large starchy, sweet-tasting tuberous roots (Nwankwo et al., 2014). The young leaves and shoots are also used as food condiments and for the preparation of local soups, plantain, rice, cocoyam, porridge yam, and beans (Bassey, 2017). The fresh root of sweet potato is rich in carbohydrates and contains appreciable amounts of $\beta$ carotene, ascorbic acid, and the amino acid, lysine, that is deficient in cereal-based diets like rice 4- 6. It also contains an appreciable amount of soluble fibre, which helps in reducing cholesterol levels and antioxidant nutrients, which can inhibit the development of coronary heart disease (Kays and Kays, 1997).

According to Selvakumar, 2014, the sweet potato is cultivated by using cutting from the flesh harvested Vine. The orangefleshed sweet potato (OFSP) vine should be planted within four days of harvest on like the white-fleshed sweet potato (WFSP), which can survive after one week of harvest. OFSP is a short duration of three to four months' maturity; however, opportunity abounds for all-round year production through water irrigation. The irrigation schedule indicates how much irrigation water should be available to the crop and how often or when this water will be applied. Irrigation scheduling can be said to be the use of water management strategies to prevent over-application of water while at the same time minimizing yield loss due to water shortage or drought stress. Often water given depends on the amount of irrigation water needed for the crop as well as the temperature of the system. Therefore, irrigation scheduling is a critical management practice for crop production (F.A.O., 2017 and Joel et al., 2012). Iren. et al. 2016, stated that continuous farming on a particular land with improper use of inorganic fertilizer reduces the fertility of the soil, which is not good for crop growth. Poku et al. 2014 and Saravaiya et al. 2010 reported that Organic fertilizer increases the fertility and the health of the soil. Hence, in check for improvement of soil fertility and available water for increased yield of sweet potato, Mucuna Pruriens pod as well as irrigation schedule were used for the study.

\section{MATERIALS AND METHODS}

\subsection{Description of the study area.}

The study was conducted in 2017 and 2018 during the dry season using irrigation. The study was done at the National Root Crops Research Institute (NRCRI), Umudike Irrigation site with Latitude of $05^{\circ} 29^{\prime} \mathrm{N}$, Longitude $07^{\circ} \mathrm{E}$ at an Altitude of $122 \mathrm{~m}$ above sea level. The minimum temperature ranges from $190 \mathrm{C}$ to $240 \mathrm{C}$, and the maximum ranges from $280 \mathrm{C}$ to 340C. The experimental site soil was sandy clay loam with 
low nutrient reserve as a result of its strong acidic nature (Lucas et al., 2012), and as such classified as Ultisol (Soil Survey, 2014). The Institute dam was used as a source of water.

\subsection{Experimental Design}

The experimental design was $1 \times 1 \times 3 \times 4$ treatments (one OFSP variety, one irrigation method, three irrigation scheduling and four fertilizer rates) were laid in a randomized c complete block design (RBCD) with three replications. The plot size was $4 \mathrm{~m} \times 5.1 \mathrm{~m}$. There was $1 \mathrm{~m}$ alley in between plots and a $2 \mathrm{~m}$ alley between reps. Below are the details of the treatments:

One variety of OFSP used was mother delight.

One irrigation method used was furrow.

Three irrigation scheduling used are

Once every two days (E2D)

Once every three days (E3D)

Once every four days (E4D)

Four fertilizer rates $0 \mathrm{~kg} / \mathrm{ha}$ (control), $200 \mathrm{~kg} / \mathrm{ha}, 400 \mathrm{~kg} / \mathrm{ha}$ and $600 \mathrm{~kg} / \mathrm{ha}$

\subsection{Mucuna pod granule preparation}

The mucuna pods collected from IITA, Ibadan was dried under room temperature to preserve the effect of excessive temperature on nitrogen content as well for easy grinding with a hammer mill. The ground mucuna pod helps in the fast released of the nutrients to the soil for the crops to absorbed them. The mucuna dried pod and the mucuna pod granule are shown in plate 2.1 and 2.2. The ground mucuna pod analyzed following standard procedures (Udo et al., 2009). The physicchemical composition of the Mucuna pod is as shown in Table 3.1. The specific weight of manure or fertilizer applied per nitrogen rate calculated based on the nitrogen content of the material using N.P.K. rate, as shown in Tables 2.1

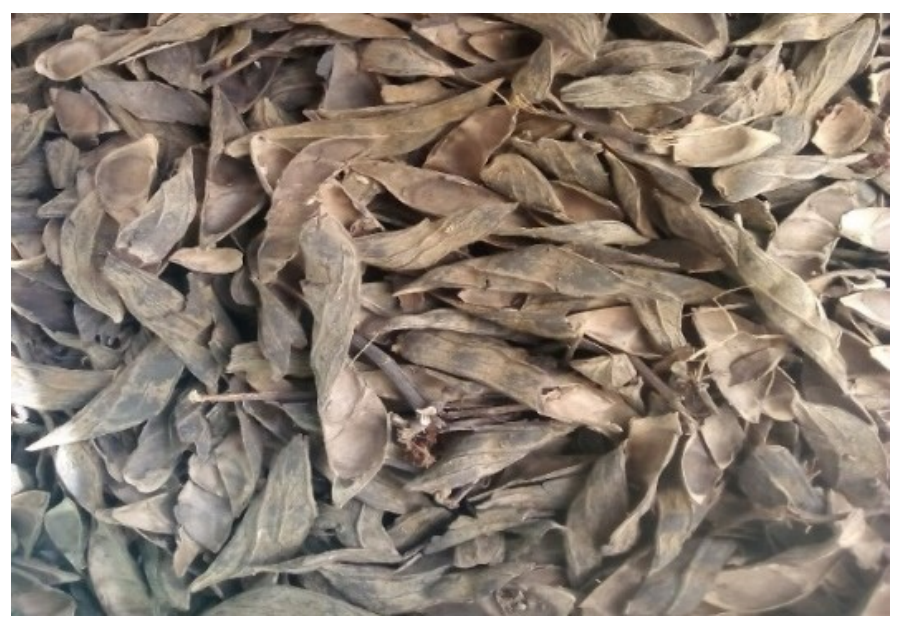

Plate 2.1: Dried Mucuna Pod

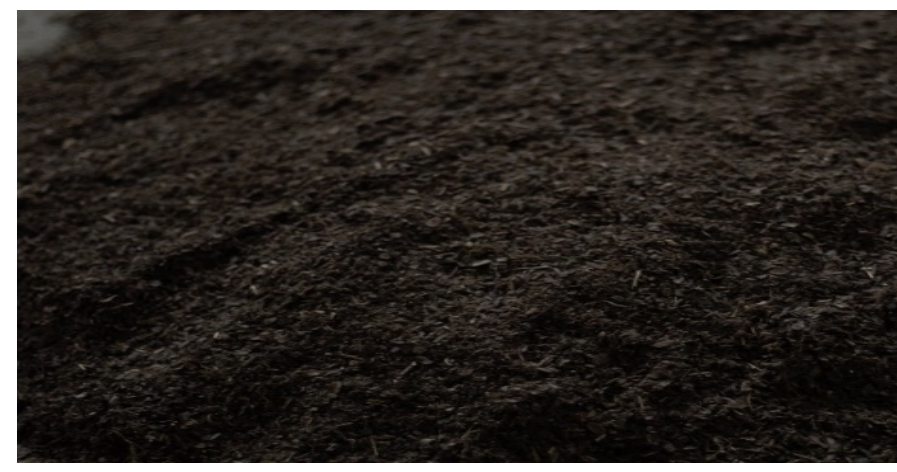

Plate 2.2: Dried Mucuna Pod Granule

Table 2.1: Treatments and Quantity per Hectare

\begin{tabular}{|c|c|}
\hline Control & no N \\
\hline Mucuna pod manure at $200 \mathrm{~kg} / \mathrm{ha}$ & $1,588.24$ \\
\hline Mucuna pod manure at $400 \mathrm{~kg} / \mathrm{ha}$ & $3,186.28$ \\
\hline Mucuna pod manure at $600 \mathrm{~kg} / \mathrm{ha}$ & $4,764.71$ \\
\hline
\end{tabular}

\subsection{Physical and chemical properties of ground mucuna pod}

Table 3.1 present the physical and chemical properties of the ground mucuna pod.

From the laboratory result, the quality of the ground mucuna pod showed that the $\mathrm{pH}$ was 6.13 , which was alkaline in nature and suitable for the growth of OFSP. It also contained nitrogen $2.05 \%$, organic matter $72.34 \%$, potassium $0.6 \%$, and phosphorous $0.4 \%$, and the other essential elements which the OFSP needed for sustaining its performance. The high organic matter level in the mucuna pod is important in the water holding capacity of the soil, which the crop needed in the dry season.

Table 2.2: Physio-Chemical Properties of Grounded Mucuna Pod

\begin{tabular}{|c|c|}
\hline Elements & $\begin{array}{c}\text { Percentage } \\
(\%)\end{array}$ \\
\hline $\mathrm{pH}$ & 6.13 \\
\hline Organic content (Org. C) & 31.09 \\
\hline Organic matter (Org. C) & 72.34 \\
\hline Nitrogen & 2.05 \\
\hline Zinc & 0.003 \\
\hline Phosphorous & 0.40 \\
\hline Iron & 0.02 \\
\hline Potassium & 0.60 \\
\hline Calcium & 1.02 \\
\hline Magnesium & 0.41 \\
\hline Sodium & 3.52 \\
\hline EC & 2.41 \\
\hline & \\
\hline
\end{tabular}

Source: Tolubanwo PhD Thesis 


\subsection{Crop Management}

i. Land Preparation: The experimental field was prepared with the use of a tractor and it's accessories to slashed, ploughed, harrowed and ridged. The ridges were than manually prepared into plots with the used of spades, field tape and rope. However, a total of 36 plots were laid out of $5.1 \times 4 \mathrm{~m}$ per plot, with a one-meter alley between plots and two meters' alley between reps.

ii. Soil Sampling: The soil sample of the experimental field was analyzed using the sampling techniques of soil auger at a depth of $0-15 \mathrm{~cm}$ and $15 \mathrm{~cm}-30 \mathrm{~cm}$. In the pre-soil analysis, as shown in Table 3.2, sample points were taken from each experimental block; these soil samples from the different points were mixed together to make a composite sample before the commencement of the analysis in the soil laboratory. The essence of the analysis was to know the present status of the soil.

iii. Planting and Fertilizer application: The mucuna pod fertilizer was incorporated into the soil two weeks before the OFSP vine was planted so that the nutrients will be made available at the right time when the crops are in need of it. Four nodes of the Vine were used as the vine length during dry season planting.

\section{iv. Irrigation Application and Agronomy Practise}

The irrigation was scheduled as E2D, E3D and E4D. This will enable one to know which of the schedules will have better yield. The same volume of water, $0.18 \mathrm{~m}^{3}$ per plot, was applied at each irrigation time across the board. Each average irrigation duration per plot was nine minutes. The agronomy practise was carried out effectively; that is; herbicide was applied one week before the vines were planted. Manual weeding was done six weeks after planting. Pesticide was used to prevent pests from destroying the leaves of the OFSP.

\subsection{Data collection and analysis}

The crop growth parameters (vine lengths were collected at 4, 8. 12WAP and at harvest with the number of leaves) and yield data (root length, root girth, numbers of root, marketable nonmarketable roots and weight of roots per stand and per hectare) collected were based on the analysis of variance (ANOVA) using the R statistical computing platform version 3.4 .4
The growth parameters collected, such as vine length at 4WAP, 8WAP, 12WAP, at harvest, as well as the number of leaves per Vine, were significantly influenced with the application of irrigation scheduling and mucuna pod at different rates. These parameters are presented in Tables 3.1 and 3.2. Under the irrigation scheduling at 4,8,12 WAP and at harvest, the maximum vine length for $2017(138.82 \mathrm{~cm}$, $1334.67 \mathrm{~cm}, 2318.93 \mathrm{~cm}$ and $3954.82 \mathrm{~cm}$, respectively) was recorded with every three days (E3D) irrigation. The once every two (E2D) was next with $110.73 \mathrm{~cm}, 1171.94 \mathrm{~cm}$, $2013.61 \mathrm{~cm}$ and $3157.36 \mathrm{~cm}$ at $4,8,12 \mathrm{WAP}$ and at harvest, respectively. The once every four days (E4D) had the least vine length. The number of leaves at harvest also showed the same trend of E3D having the highest leaves of 1608, followed by E2D of 1077 and E4D had the least of 878. The trend in the vine yield under irrigation scheduling revealed that OFSP does not need excessive or under irrigation. That was why the E3D gave the best vine yield throughout the trend. Also, in table 3.1, under fertilizer rate, control at 4WAP had the lowest length of $6.75 \mathrm{~cm} /$ plant while mucuna at M600 had the highest length of $221 \mathrm{~cm} /$ plant. At $8 \mathrm{WAP}$, the fertilizer rate application was highly significant $(\mathrm{P}<0.001)$. From the trend of the fertilizer rate, the control had the lowest length of $563.11 \mathrm{~cm} /$ plant, while the highest length was found with mucuna at M600, which gave $1,682.22 \mathrm{~cm} /$ plant. At 12WAP length, the fertilizer rates were highly significant $(\mathrm{P}<0.001)$. The control had $1,031 \mathrm{~cm} /$ plant, Mucuna at M600 application had the highest length of $3,239.17 \mathrm{~cm} /$ plant. At harvest, it also revealed that the control treatment had the lowest length of $1,605.64 \mathrm{~cm} /$ plant while the application of mucuna at M600 gave the highest length of 4,972.17 cm/plant. This increase in the length is a result of the available nutrients in the mucuna pod granule. The above result is in line with Hirich et al. (2014) and Nedunchezhiyan et al. (2012), who indicated that a higher level of organic amendment of soil increased yield with proper irrigation frequency.

Table 3.2 also revealed that in 2018, vine length at 12 W.A.P., harvest and number of leaves vine at harvest were highly significant $(\mathrm{P}<0.001)$. The E3D had the highest values of vine length from 8,12 W.A.P. at harvest for both Vine and leaves of $1,709.42 \mathrm{~cm}, \quad 3,004.50 \mathrm{~cm}, 3,366.01 \mathrm{~cm}$ and $1,063.96$ numbers of leaves, respectively.

\section{RESULTS AND DISCUSSIONS}

\subsection{Effects of irrigation scheduling, fertilizer (mucuna pod) rates on OFSP growth Parameters}

Table 3.1: Effects of irrigation scheduling, fertilizer (mucuna pod) rates on OFSP growth parameters for 2017

\begin{tabular}{|c|c|c|c|c|c|}
\hline \multirow{2}{*}{$\begin{array}{c}\text { Treatment } \\
\text { Irrigation scheduling }\end{array}$} & \multicolumn{4}{|c|}{ Growth Parameters } \\
\cline { 2 - 6 } & 4 WAP & 8 WAP & 12 WAP & Harvest & leaves vine at \\
harvest & \\
\hline & $110.73 b$ & $1171.94 \mathrm{~b}$ & $2013.61 \mathrm{~b}$ & $3157.36 \mathrm{~b}$ & $1077.36 \mathrm{~b}$ \\
\hline E2D & $138.82 \mathrm{a}$ & $1334.67 \mathrm{a}$ & $2318.93 \mathrm{a}$ & $3954.82 \mathrm{a}$ & $1607.50 \mathrm{a}$ \\
\hline E3D & $93,39 \mathrm{c}$ & $1021.37 \mathrm{c}$ & $1862.35 \mathrm{~b}$ & $2722.05 \mathrm{c}$ & $878.38 \mathrm{c}$ \\
\hline E4D & & & & \multicolumn{2}{|c|}{ Vine Length (cm) } \\
\hline
\end{tabular}




\begin{tabular}{|c|c|c|c|c|c|}
\hline LSD & 13.806 & 62.9410 & 227.3615 & 391.2757 & 127.1248 \\
\hline Fertilizer rate & & & & & $507.00 \mathrm{f}$ \\
\hline M0 & $6.75 \mathrm{e}$ & $563.11 \mathrm{f}$ & $1031.00 \mathrm{e}$ & $1605.64 \mathrm{f}$ & $934.44 \mathrm{~d}$ \\
\hline M200 & $95.89 \mathrm{c}$ & $1065.94 \mathrm{~d}$ & $1933.17 \mathrm{c}$ & $2822.56 \mathrm{de}$ & $1570.22 \mathrm{~b}$ \\
\hline M400 & $171.17 \mathrm{~b}$ & $1446.00 \mathrm{c}$ & $2470.44 \mathrm{~b}$ & $4162.28 \mathrm{~b}$ & $1862.44 \mathrm{a}$ \\
\hline M600 & $221.00 \mathrm{a}$ & $1682.22 \mathrm{a}$ & $3239.17 \mathrm{a}$ & $4972.17 \mathrm{a}$ & 194.1864 \\
\hline LSD & 21.0868 & 96.1439 & 347.3004 & 597.6748 & \\
\hline
\end{tabular}

Table 3.2: Effects of irrigation scheduling, fertilizer (mucuna pod) rates on OFSP growth parameters for 2018

\begin{tabular}{|c|c|c|c|c|c|}
\hline \multirow{3}{*}{$\begin{array}{c}\text { Treatment } \\
\text { Irrigation scheduling }\end{array}$} & \multicolumn{5}{|c|}{ Growth Parameters } \\
\hline & \multicolumn{4}{|c|}{ Vine Length (cm) } & \multirow{2}{*}{$\begin{array}{c}\text { No of leaves vine at } \\
\text { harvest }\end{array}$} \\
\hline & 4WAP & 8WAP & 12WAP & Harvest & \\
\hline E2D & $42.44 \mathrm{a}$ & $1327.42 \mathrm{a}$ & $2460.25 b$ & $2289.92 b$ & $687.69 b$ \\
\hline E3D & $42.30 \mathrm{a}$ & $1709.42 \mathrm{a}$ & $3004.50 \mathrm{a}$ & $3366.01 \mathrm{a}$ & $1063.96 a$ \\
\hline E4D & $37.25 \mathrm{a}$ & $1093.57 \mathrm{a}$ & $2109.50 \mathrm{c}$ & $1817.64 \mathrm{c}$ & $533.29 \mathrm{~b}$ \\
\hline LSD & NS & NS & 213.61 & 374.1436 & 173.9268 \\
\hline \multicolumn{6}{|l|}{ Fertilizer rate } \\
\hline M0 & $26.53 \mathrm{~d}$ & $700.08 \mathrm{c}$ & $1394.20 \mathrm{~d}$ & $954.68 \mathrm{~d}$ & $283.4 \mathrm{c}$ \\
\hline M200 & $40.22 \mathrm{c}$ & $974.37 \mathrm{~b}$ & $1906.25 \mathrm{c}$ & $1782.66 \mathrm{c}$ & $579.02 b$ \\
\hline M400 & $51.33 \mathrm{~b}$ & $1589.76 \mathrm{a}$ & $2872.65 b$ & $3183.36 \mathrm{~b}$ & $956.46 \mathrm{c}$ \\
\hline M600 & $62.56 \mathrm{a}$ & $1978.05 \mathrm{a}$ & $3581.69 \mathrm{a}$ & $3761.88 \mathrm{a}$ & $1170.66 \mathrm{a}$ \\
\hline LSD & 6.6798 & 350.1239 & 319.7153 & 576.0986 & 269.2352 \\
\hline
\end{tabular}

In 2018 as presented in table 3.2 , the fertilizer rate was highly significant $(\mathrm{P}<0.001)$ throughout 4,8 and 12 W.A.P. as well as harvest for both vine length and number of leaves at harvest. In the fertilizer rate application, M600 gave the highest yield parameter of $62.56 \mathrm{~cm}, 1,978.05 \mathrm{~cm}, 3,581.69 \mathrm{~cm}, 3,761.88 \mathrm{~cm}$ vine length and $1,170.66$ numbers of leaves for 4,8 and 12 W.A.P. as well as harvest for both vine length and number of leaves at harvest. The result is also in agreement with researchers Iren et al. (2016) and Maobe et al. (2011) that organic manures are generally superior in improving the soil availability of soil minerals for plant growth.As presented in tables 3.3 and 3.4 for 2017 and 2018, the significant influence of irrigation scheduling on weight of vine leaves ( $t / h a$ ), number of root per stand, weight of root per stand, root length per stand, root girth per stand, total root yield ( $t / h a)$ and marketable roots yield ( $t / h a)$ was explained by every three days' irrigation (E3D) which had the highest values in all the data collected.

Table 3.4: Effects of irrigation scheduling, fertilizer (mucuna pod) rates on OFSP root yieldparameters at harvest for 2017

\begin{tabular}{|c|c|c|c|c|c|c|c|}
\hline \multirow{2}{*}{$\begin{array}{c}\text { Treatment } \\
\begin{array}{c}\text { Irrigation } \\
\text { Scheduling }\end{array}\end{array}$} & $\begin{array}{c}\text { Wt. of vine } \\
\text { leave (vl) (t/ha) }\end{array}$ & $\begin{array}{c}\text { No of root } \\
\text { /stand }\end{array}$ & $\begin{array}{c}\text { Wt.of root/ } \\
\text { stand(kg) }\end{array}$ & $\begin{array}{c}\text { Root } \\
\text { length/ } \\
\text { Stand(cm) }\end{array}$ & $\begin{array}{c}\text { Root girth/ } \\
\text { Stand } \\
(\mathrm{cm})\end{array}$ & $\begin{array}{c}\text { Total root } \\
\text { yield (t/ha }\end{array}$ & $\begin{array}{c}\text { Marketable } \\
\text { rootyield (t/ha) }\end{array}$ \\
\hline E2D & 21.04 & $2.73 \mathrm{~b}$ & $2.19 \mathrm{~b}$ & $68.28 \mathrm{a}$ & $29.13 \mathrm{~b}$ & $13.86 \mathrm{~b}$ & $12.92 \mathrm{~b}$ \\
\hline E3D & 27.03 & $3.08 \mathrm{a}$ & $2.51 \mathrm{a}$ & $72.68 \mathrm{a}$ & $32.63 \mathrm{a}$ & $16.28 \mathrm{a}$ & $15.23 \mathrm{a}$ \\
\hline E4D & 17.63 & $2.37 \mathrm{c}$ & $2.01 \mathrm{c}$ & $58.10 \mathrm{a}$ & $21.51 \mathrm{c}$ & $11.12 \mathrm{c}$ & $10.28 \mathrm{c}$ \\
\hline LSD & 3.064 & 0.7187 & 0.1421 & 6.9487 & 3.2174 & 2.4172 & 1.6132 \\
\hline Fertilizer rate & & & & & & & \\
\hline 0M & 10.58 & $2.54 \mathrm{ab}$ & $0.76 \mathrm{~d}$ & $52.03 \mathrm{~b}$ & $13.68 \mathrm{~d}$ & $6.88 \mathrm{~d}$ & $6.07 \mathrm{~d}$ \\
\hline 200M & 16.22 & $2.98 \mathrm{ab}$ & $2.06 \mathrm{c}$ & $68.98 \mathrm{ab}$ & $24.21 \mathrm{c}$ & $11.27 \mathrm{c}$ & $10.48 \mathrm{c}$ \\
\hline $400 \mathrm{M}$ & 25.71 & $3.04 \mathrm{a}$ & $2.75 \mathrm{~b}$ & $73.09 \mathrm{ab}$ & $34.84 \mathrm{~b}$ & $16.78 \mathrm{~b}$ & $15.76 \mathrm{~b}$ \\
\hline $600 \mathrm{M}$ & 31.77 & $3.48 \mathrm{a}$ & $3.21 \mathrm{a}$ & $95.75 \mathrm{a}$ & $42.62 \mathrm{a}$ & $20.78 \mathrm{a}$ & $19.47 \mathrm{a}$ \\
\hline LSD & 9.6285 & NS & 0.2171 & NS & 4.9148 & 6.5721 & 5.5162 \\
\hline
\end{tabular}


According to Nedunchezhiyan et al. (2012) that proper irrigation scheduling and application result in higher root yield and vine production. The E3D did not significantly increase the number of roots in table 3.3 of 2017 , while others were significantly increased. In table 3.4 of 2018 , E3D significantly increase weight of vine leaves $(\mathrm{t} / \mathrm{ha})$, number of root per stand, weight of root per stand, root length per stand, root girth per stand, total root yield (t/ha) and marketable roots yield ( $t / h a)$. When E2D, E3D and E4D are compared, E3D gave higher values, followed by E2D and E4D gave the lest value. Nevertheless, this might be due to the fact that over and under irrigation is not ideal if we need a good increase in yield. Mucuna fertilizer rates had a significant effect weight of vine leaves (t/ha), number of root per stand, weight of root per stand, root length per stand, root girth per stand, total root yield ( $\mathrm{t} / \mathrm{ha}$ ) and marketable roots yield (t/ha) as presented in tables 3.3 and 3.4. This showed that mucuna fertilizer application increases the yield of sweet potato as the mucuna rate increases but not the number of roots per stand. The mucuna fertilizer rates were highly significant $(\mathrm{P}<0.001)$, as shown by yield components. These could be due to the beneficial effect of the various components present in the mucuna pod. The result agrees with the reports by Jari et al. (2015) and Yeng et al. (2012) that nitrogen and other components promotes cell division, growth and increases the yield of sweet potato through the formation of large-sized tuber roots. From the figures in the tables, it can be reported that sweet potato yield increased with an increase in the rate of mucuna fertilizer from M200 to $\mathrm{M} 600 \mathrm{~kg} / \mathrm{ha}$. According to this finding, the greatest sweet potato yield was obtained with M600 kg/ha. In this study, however, all yield components of M0 were far below the yield of M200/ha, suggesting that the $\mathrm{M} 200 \mathrm{~kg} / \mathrm{ha}$ is not adequate for sweet potato yield in the study area. However, the nutrient of the soil could become limiting due to continuous cultivation. Also, it was observed that the treatment with the highest mucuna rate of M600/ha growth produced the highest yield, indicating a positive influence of mucuna fertilizer on sweet potato yield. The total cost of production (input) for both NPK and Mucuna for 2017 and 2018 was $\mathrm{N} 200,760.5$ and N210,921.6 respectively. The produces (vine and roots) which is the output sold was N444,900 and N637,000 for NPK and Mucuna. Profit margin is N238,139.5 for NPK and N426,078.4 Mucuna. This is in agreement with the above researchers.

\section{CONCLUSIONS AND RECOMMENDATIONS}

The study revealed that E3D (Irrigation once every three days) gave the greatest growth and yield and that the application of mucuna fertilizer has the potential of increasing the growth and yield of sweet potato in which the greatest growth and yield were obtained with M600/ha. A combination of E3D and M600/ha will give maximum sweet potato production, which can be recommended for farmers during dry season farming. Farmers can also be encouraged to use the mucuna pod as organic fertilizer during the on season farming.

\section{REFERENCE}

[1] Bassey, E. E. (2017). Variability in the Yield and Character Association in Nigerian Sweet Potato (Ipomoea batatas (L.) Lam) Genotypes. World Journal of Agricultural Sciences Vol.5(01),pp.066-074,January, 2017 Available online at http://wsrjournals.org/journal/wjas $\quad$ ISSN 2329-9312 (C)2017 World Science Research Journals

[2] F.A.O., (2017). Water for Sustainable Food and Agriculture A Report Produced for The G20 Presidency of GermanyFood and Agriculture Organization of the United Nations Rome, ISBN 978-92-5-109977-3.

[3] Harvest Plus, c/o IFPRI, $2033 \mathrm{~K}$ Street, NW, Washington, DC 20006-1002 USA Tel: +1-202-862-5600 • Fax: +1-202-467-4439 • HarvestPlus@cgiar.org・www.HarvestPlus.org

[4] Iren, O.B., Udoh, D.J., Asawalam, D.O. and Osodeke, V.E. (2016). The Comparative Effects of Different Nitrogen Sources and Rates on Soil Properties and Yield of Amaranthus Cruentus. European Journal of Academic Essays 3(9); 304 - 311.

[5] Jari, S., Mani, H. and Muhammad, A. (2015). Performance of Sweet Potato (Ipomea batatas L) As Affected by Irrigation Scheduling and N.P.K. Fertilizer Rates at Kaduna, Kano State Nigeria. FUDMA J. Agric. And Agric-Tech, Volume 1, No 1, Pages 51-55.

[6] Joel P. Schneekloth, David C. Nielsen, Alan Schlegel (2012); Irrigation Capacity Impact on Limited. Irrigation Management and Cropping Systems; Proceedings of the 24th Annual Central Plains Irrigation Conference, Colby, Kansas, February 21-22, 2012 Available from CPIA, 760 N. Thompson, Colby, Kansas.

[7] Kays S. J., Kays S. E. (1997): Sweet Potato Chemistry in Relation to Health. Proceedings, International Workshop on Sweet Potato Production System Toward the21st Century December 9-10, Miyakonojo, Miyazaki, Japan, p. 231.

[8] Lucas, P., Irena, F.C., Charles, G.T. (2012); Sinking of Heterosigma Akashiwo Results in Increased Toxicity of This Harmful Algal Bloom Species. Elsevier PublicationHarmful Algae, Vol. 13, Jan 2012.

[9] Maobe, S.N., Akundabweni, L.S.M, Nfburu, M W.K., Ndufa, J.K., Mureithi, J.G., Gachene, C.K.K., Makini, F W. and Okello, J.J. (2010): Effect of Mucuna Green Manure and Inorganic Fertilizer Urea Nitrogen Sources and Application Rates on Harvest Index of Maize (Zea mays L.); World Journal of Agricultural Sciences 6 (5): 532-539, 2010, ISSN 1817-3047, C)! D.O.S.! Publications, 2010.

[10] Nedunchezhiya, M., Byju, G. and Ray, R.C. (2012). Effect of Tillage, Irrigation and Nutrient Level on Growth and Yield of Sweet Potato in Ice Fallow. International Scholarly Research Network ISRN Agronomy. Volume 2012, ID 291285, 13 pages.

[11] Nwankwo, I.I.M, and Bassey, E.E. (2014). Breeding sweet potato for food in Nigeria, In: $\quad$ Etim, L., Udo, J. P., Etim, N., Ekwu, A. (Editors). Contemporary Issues in Sustainable Tropical Agriculture, Faculty of Agriculture, University of J.O. Uyo, Nigeria, pp. 278-285

[12] Poku, P. A, Agyarko, K., Dapaah, H. K. and Dawuda,M.M. (2014). Influence of Mucuna Pruriens Green Manure, N.P.K. and Chicken. Manure Amendment on Soil Physico-Chemical Properties and Growth and Yield of Carrot (Daucus Carota L.). Journal of Agriculture and Sustainability. Volume 5, Number 1, $2014,26-44$.

[13] Udo, E J., Ibia, T.O., Ogunwale, J.O., Ano, A.O. and Esu, I. (2009). Manual of Soil, Plant and Water Analysis. Sibon Books Ltd. Lagos.

[14] Saravaiya, S.N., Chaudhary,P.P, Patel,D.A., Patel, N.B. Aahir, M.P. and Patel, V.L. (2010). Influence of Integrated Nutrient Management (I.N.M.) on Growth and Yield Parament of Elephant Foot Yam under South Gujrat Condition. The Asian Journal of Horticulture, 5(1):58-60

[15] Selvakumar, R.A.(2014). Textbook of Glautus Olericulture New Vishal Publications, New Delhi, Pages 478-482

[16] Sheth, S.G., Desai, K.D. Patil, S.J., Navya K and Chaudhari V.L. (2017). The Effect of Integrated Nutrient Management on 
Growth, Yield and Quality of Sweet Potato [Ipomoea batatas (L.) Lam]. International Journal of Chemical Studies; 5(4):346-349.

[17] Soil Survey Staff, (2014). Keys to Soil Taxonomy United States Department of Agriculture Natural Resources Conservation Service Twelfth Edition. Pages 283 - 304

[18] Yeng, S. B., Agyarko, K., Dapaah, H. K., Adomako, W. J. and Asare, E. (2012) Growth and Yield of Sweet Potato (Ipomoea batatas L.) as Influenced by Integrated Application of Chicken Manure and Inorganic Fertilizer. African Journal of Agricultural Research Vol. 7(39), pp. 5387-5395 Available online at http://www.academicjournals.org/ AJAR

DOI:10.5897/AJAR12.1447 ISSN 1991-637X (C2012 Academic Journals. 